\title{
The Harder the Brexit, the Harder the Impact on Northern Ireland
}

Very few analysts would have predicted three years ago that the question of the Irish border might be the rock upon which the Brexit dream would perish. In 2016, as the debate on the merits and demerits of Brexit raged across the United Kingdom, it focused on industry, sovereignty, outsourced labour and of course immigration. Those who flagged the potential for the breakdown of peace in Northern Ireland or the ultimate rupture of the union due to the anger of Scottish nationalists, were drowned out in a debate obsessed by the narrow concerns of 'Little England'.

Three years on, the question of the Northern Ireland border has been front and centre throughout the tortuous negotiations between the UK and the EU. Those who dismissed this question during the referendum campaign can no longer pretend that such concerns are inconsequential. The Irish Government, supported by the European Union, ensured that the border question was central to the Article 50 negotiations and it continues to be a key stumbling block to securing an agreement between both sides, with just days to go before the UK's departure date.

What Brexiteers failed to understand before and after the Brexit vote is that inhabitants of the devolved territories within the United Kingdom view the European Union in an entirely different light to those in some of the hard Brexit English heartlands. Citizens in Northern Ireland, in particular, feel economically and politically marginalised. Many resent their economic dependence on London, while believing that decision-makers in the UK capital are often out of touch with their priorities and concerns.

On the other hand, the sentiment towards the European Union is relatively positive. Northern Ireland is a beneficiary of significant EU funding programmes, which is understood and felt by the people.

The Northern Ireland dependence on the UK, along with the EU, means that the optimum outcome for Northern Ireland's economy is for the UK as a whole to remain in the EU. The EU's regional policy has played a crucial role in the economic and social development of Northern Ireland. Between 2007-2013, the EU co-funded programmes for the North that totalled 3.45 billion euro with the vast bulk, 2.6 billion euro, issued via the Common Agricultural Policy (CAP). The current EU budget from 2014-2020 will see the North receive 3.55 billion euro - of which 230 million euro has been set aside for peace projects. It goes without saying that future EU funding is under threat in the event of a UK departure.

The interdependence of the so called 'All Island Economy' - the combined economies of Northern Ireland and the Republic of Ireland - is significant and growing. Cross-border trade in goods achieved a record high of six billion British pounds or seven billion euro in 2017 , with average growth of four percent per annum achieved over the past 20 years.

The cross border population, including the six counties of Northern Ireland and the northerly counties of the Republic, is approximately 850,000 people and is predominantly rural. A Queen's University study of people living in this cross border region showed that $73 \%$ believe Brexit will affect their community "to a great extent" and that the most important aspects of EU membership are citizenship rights and funding.

There is no doubt that the harder the Brexit, the harder the impact on Northern Ireland and the border counties in the Republic of Ireland. Assuming that the UK does in fact depart the 
European Union, it is undoubtedly the will of the people of Northern Ireland (who voted to remain in 2016) and in the best interests of the people that the UK maintain a customs union arrangement and full regulatory alignment with the EU. Anything short of this will require customs checks, border controls and devastating disruption to the trade and economic growth which has been enjoyed on both sides of the border over the past two decades.

Naturally, a 'No Deal' Brexit would be a disaster. We have had a glimpse of what this would look like in the past few weeks. The introduction of the tariff regime set out by the UK Government in the event of No Deal would have a detrimental effect on the agri-food sector in Northern Ireland allowing for cheaper, unregulated food to flood the market, thereby undermining local producers. The Ulster Farmers' Union, which is the largest farming organisation in Northern Ireland representing approximately 11,500 farming families, has warned that a cliff-edge scenario would be "disastrous for British farming and food production". The organisation has noted that of the 360 million pounds total income for Northern Ireland farmers for the financial year 2018-19, 286 million pounds will come from direct support from CAP.

The UK Government also tellingly noted in a report last month that the cumulative impact of No Deal would be more severe in Northern Ireland than in Great Britain and that it would last longer. The report cites interwoven cross-border supply chains in both the production stage and in finished products. It identified the risk that businesses will fail or relocate to Ireland as a result. Northern Ireland has a high reliance on SMEs which account for 75\% of private sector employment. The Government's report identified this noting: "The agrifood sector is a disproportionately large part of Northern Ireland's economy and located predominantly in border/rural areas. It is particularly vulnerable given its reliance on crossborder supply chains in the production stage and in finished products".

The economic implications of a No Deal Brexit are stark, but possibly less focus has been afforded to the likely political fallout, which threatens to be explosive. Brexit has already frayed the delicate political balance in Northern Ireland. The devolved Northern Executive (effectively Northern Ireland's Government) has not resumed office since elections were held two years ago. The region is leaderless - at least in part because of Brexit.

Political tensions are rising, with some signs of dissident paramilitary forces re-emerging against the backdrop of political disarray. Last month a car bomb was planted in the city of Derry, bringing back haunting memories of the terrorist activity which was a part of life in Northern Ireland until the Good Friday peace agreement was signed in 1998.

Let there be no doubt, if the UK leaves the European Union without a deal, a hard border on the island of Ireland will be unavoidable. It will be demanded to protect the integrity of the Single Market and it will be required by WTO rules should the UK enter into free trade agreements with third countries. The erection of a physical border infrastructure between the north and south of Ireland will lead to a rapid deterioration in the fragile peace that exists in the north. Border posts, manned by the Police Service of Northern Ireland, or the British Army, will become inevitable targets for dissident terrorist groups in the north. There is a strong likelihood that such activity will spill over to the south of Ireland and mainland Great Britain.

Those advocating in favour of a hard Brexit have no idea, or perhaps no concern, for the economic and political carnage this would cause in Northern Ireland. They wilfully bury their heads in the sand and deny the very real threats which are clear to anyone familiar with Northern Ireland and its politics. There are many reasons to hope for No Brexit or Soft Brexit, but surely securing peace and saving lives in Northern Ireland has to be the most compelling of all.

Lucinda Creighton, Vulcan Consulting Ltd., Dublin, Ireland. 